\title{
Incidence of Delayed Puberty in Cattle Heifers in and around Jabalpur
}

\author{
P. K. Patel*, S. N. Shukla and G. Singh \\ Department of Veterinary Gynaecology and Obstetrics, College of Veterinary Science and \\ Animal Husbandry, NDVSU, Jabalpur-482001, India \\ *Corresponding author
}

\section{Keywords}

Delayed puberty,

Cattle heifers,

Jabalpur, Madhya

Pradesh

\section{Article Info}

Accepted:

18 May 2020

Available Online:

10 June 2020

\section{A B S T R A C T}

The incidence of delayed puberty was studied in 500 cattle heifers in and around Jabalpur. The heifers with history of non-exhibition of estrus and smooth ovaries (without follicles or corpus luteum) during gynaecological examination were considered as delayed pubertal. The overall incidence of delayed puberty was found $44.44 \%$. The analysis of result on breed wise incidence revealed $52.92 \%, 29.21 \%, 57.89 \%$ and $41.67 \%$ in non-descript, crossbred, Gir and Sahiwal breeds, respectively. The results revealed higher incidence of delayed puberty $(68.92 \%)$ in heifers with body condition score (BCS) below 2 as compared to BCS more than 2 (31.08\%). It can be concluded from this study that delayed puberty is one of the cause of anoestrus and thus prolonged calving interval in rural cattle. Further, higher incidence of delayed puberty persists in indigenous and nondescript rural cattle heifers of poor body condition score.

\section{Introduction}

Puberty is the period when the sexual organs are functionally developed. Puberty in heifers is characterized by first ovulation and plasma progesterone concentration above $1 \mathrm{ng} / \mathrm{ml}$ (Post and Reich, 1980).The fundamental requirement for onset of puberty is the secretion of GnRH from the hypothalamus. Many factors like species, genetics, nutrition, body weight, role of different hormones, health and other managemental condition have direct and indirect effect on growth, puberty and sexual maturity (Gupta et al., 2016). The body weight gain may have greater influence on onset of puberty.

About 60 to $65 \%$ of mature body weight may be standard during starting of breeding season in heifers (Endecott et al., 2013). Incidence of anoestrus in heifers has been reported between 12.37 to 64.66 percent (Luktuke and Sharma, 1978; Naidu and Rao, 1981; Sinha et al., 1987). 
Dantre (1997) reported 21.62 percent mean incidence of delayed puberty in crossbred heifers under farm condition. A cow maturing in early age will produce more milk in its whole lifetime. In the tropical and subtropical condition the age at puberty in Bos indicus is between 16 and 40 months with a mean of 25 months, i.e., 6-12 months later than Bos taurus (Abeygunawardena and Dematawewa, 2004).

Among the reproductive disorders, delayed puberty or pubertal anoestrus is the most important and challenging problem. Delayed puberty is a problem of both farm-bred as well as heifers under rural condition.

\section{Materials and Methods}

The incidence of delayed puberty was studied in 500 cattle heifers in villages adopted by university and adjoining villages in Jabalpur Madhya Pradesh. The detailed information of cattle heifers provided by the owners and findings of gynaecological examination were recorded during the study.

The age, body weight, first sign of estrus and body condition score were recorded. The suspected delayed pubertal heifers were examined per rectally for ascertaining the ovarian function i.e. presence of follicles or corpus luteum.

The heifers with history of non-exhibition of estrus since birth and smooth ovaries (without follicles or corpus luteum) in two consecutive gynaecological examinations at 10 days apart were considered as delayed pubertal. The incidence of delayed puberty was studied breed-wise and data were also correlated with body condition score (BCS).

\section{Results and Discussion}

The incidence of delayed puberty in different breeds during study were found $52.92 \%$ in
Non-descript, $29.21 \%$ in Cross-bred, $57.89 \%$ in Gir and $41.67 \%$ in Sahiwal breed. The overall incidence of delayed puberty was observed to be $44.44 \%$ in cattle heifers (Table 01).

Almost similar incidence (31.57\%) of anoestrus in crossbred heifers was also reported by Chetty and Rao (1987) whereas Luktuke (1977) reported little higher incidence i.e. $36.16 \%$ in crossbred heifers.

Very high incidence i.e. $64.24 \%$ and $59.82 \%$ in crossbred heifers were reported by Sinha $e t$ al., (1987) and Singh et al., (1987), respectively. However, Naidu and Rao (1981) reported low incidence $(12.37 \%)$ in crossbred heifers as compared to the present study.

Higher incidence of delayed puberty in this study may be attributable to malnutrition, poor managemental practices and environmental factors as most of the animals were taken from unorganized rearing system. The data on breed-wise analysis of delayed puberty was also classified on the basis body condition score of heifers (Table 02) and the results revealed higher incidence of delayed puberty $(68.92 \%)$ in heifers with body condition score below 2 as compared to BCS more than $2(31.08 \%)$.

Among the delayed pubertal heifers of different breed, the below average body condition score was recorded $72.73 \%$ in Nondescript, 57.69\% in crossbred, 63.64\% in Gir and $80 \%$ in Sahiwal heifers.

Present findings supported the reports of Maina et al., (2008) who concluded that the incidences of anoestrus and abnormal ovarian activity are negatively correlated to body condition score. Vacek et al., (2015) reported that the heifers with good body condition score have more average daily gain and early age at first AI. 
Table.1 Breed wise incidence of delayed puberty in cattle heifers

\begin{tabular}{|l|c|c|c|}
\hline \multirow{2}{*}{ Breed } & \multirow{2}{*}{$\begin{array}{c}\text { Animal } \\
\text { surveyed (n) }\end{array}$} & \multicolumn{2}{c|}{ Incidence of delayed puberty } \\
\cline { 3 - 4 } & 291 & 154 & N \\
\hline Non-descript & 178 & 52 & 52.92 \\
\hline Cross-bred & 19 & 11 & 29.21 \\
\hline Gir & 12 & 05 & 57.89 \\
\hline Sahiwal & $\mathbf{5 0 0}$ & $\mathbf{2 2 2}$ & 41.67 \\
\hline Total & & & $\mathbf{4 4 . 4 4}$ \\
\hline
\end{tabular}

Table.2 Incidence of delayed puberty in cattle heifers in relation to body condition score

\begin{tabular}{|l|c|c|c|c|c|}
\hline \multirow{2}{*}{ Breed } & $\begin{array}{c}\text { Delayed pubertal } \\
\text { heifers }\end{array}$ & \multicolumn{4}{|c|}{ Incidence of delayed puberty } \\
\cline { 3 - 6 } & $(\mathbf{n})$ & \multicolumn{2}{|c|}{ BCS $\leq \mathbf{2}$} & \multicolumn{2}{c|}{ BCS $>\mathbf{2}$} \\
\hline Non-descript & 154 & $\mathbf{n}$ & $\mathbf{\%}$ & $\mathbf{N}$ & $\mathbf{\%}$ \\
\hline Cross-bred & 52 & 30 & 57.69 & 22 & 42.31 \\
\hline Gir & 11 & 07 & 63.64 & 04 & 36.36 \\
\hline Sahiwal & 05 & 04 & 80.00 & 01 & 20.00 \\
\hline Total & $\mathbf{2 2 2}$ & $\mathbf{1 5 3}$ & $\mathbf{6 8 . 9 2}$ & $\mathbf{6 9}$ & $\mathbf{3 1 . 0 8}$ \\
\hline
\end{tabular}

It can be concluded from this study that delayed puberty is one of the cause of anoestrus and thus prolonged calving interval in rural cows. Further, higher incidence of delayed puberty persists in indigenous and nondescript rural cattle heifers especially of poor body condition score which may be due to malnutrition.

\section{References}

Abeygunawardena, $H$. and Dematawewa, C.M.B. 2004. Prepubertal and postpartum anoestrus in tropical zebu cattle. Animal Reproduction Science, 82: 373-387.

Chetty, A.V. and Rao, A.R. 1987. Incidence of infertility among crossbred cattle of Chittoor District. Livestock Advisor, 12: 45-48.

Dantre, U.K. 1997. Induction of estrus in delayed pubertal crossbred heifers treated with Receptal and long acting steroid preparation. M.V.Sc. Thesis
(Animal Reproduction, Gynaecology and Obstetrics), J.N.K.V.V., Jabalpur.

Endecott, R.L., Funston, R.N., Mulliniks, J.T. and Roberts, A.J. 2013. Implications of beef heifer development systems and lifetime productivity. Journal of Animal Science, 91: 1329-1335.

Gupta, S.K., Singh, P., Shinde, K.P., Lone, S.A., Kumar, N. and Kumar, A. 2016. Strategies for attaining early puberty in cattle and buffalo. Agriculture Reviews, 37(2): 160-167.

Luktuke, S.N. 1977. Gynaecological studies in the rural cattle and buffaloes and measures for augmenting their breeding efficiency. Indian Dairyman, 29: 281284.

Luktuke, S.N. and Sharma, C. 1978. Studies on incidence of true anoestrus in rural cattle and buffaloes. Indian Veterinary Journal, 55: 940-942.

Maina, V.A., Muktar, A. and Sabo, Y.G. 2008. Effects of body condition score on ovarian activity of Bos indicus 
(zebu) cows. Asian Journal of Scientific Research, 1(4): 421-428.

Naidu, K.V. and Rao, A.R. 1981. Incidence of infertility among cross-bred cattle of Andhra Pradesh. Indian Journal of Animal Science, 51(9): 829-831.

Post T.B. and Reich M.M. 1980. Puberty in tropical breeds of heifers as monitored by plasma progesterone. Proceedings of the Australian Society of Animal Production, 13: 61-62.

Singh, J., Singh, B.K. and Sinha, M.P. 1987. Incidence of anoestrum among crossbred cattle (Holstein X Local) of
Chotanagpur region. Indian Journal of Animal Reproduction, 8(2): 105-107.

Sinha, B.P., Sinha, S.N. and Singh, B. 1987. Incidence of anoestrum in crossbred cattle in field and farm condition. Livestock Advisor, 12(32): 43-48.

Vacek, M., Krpalkova, L., Syrucek, J., Stipkova, M. and Janecka, M. 2015. Relationship between growth and body condition development during the rearing period and performance in the first three lactations in Holstein cows. Czech Journal of Animal Science, 60(9): 417-425.

\section{How to cite this article:}

Patel. P. K., S. N. Shukla and Singh. G. 2020. Incidence of Delayed Puberty in Cattle Heifers in and around Jabalpur. Int.J.Curr.Microbiol.App.Sci. 9(06): 1289-1292. doi: https://doi.org/10.20546/ijcmas.2020.906.160 